\title{
Pensions ANd FeRTILITy InCENTIVES
}

\author{
ROBERT FENGE \\ VOLKER MEIER
}

CESIFo Working PAPER No. 879

CATEGORY 1: PUblic FinANCE

FEBRUARY 2003

An electronic version of the paper may be downloaded

- from the SSRN website:

www.SSRN.com

- from the CESifo website:

www.CESifo.de 


\title{
PENSIONS AND FERTILITY INCENTIVES
}

\begin{abstract}
This paper discusses the efficiency of a pay-as-you-go pension reform by introducing a child benefit in an endogenous fertility setting. In the model of a small open economy, higher fertility is associated with a reduction of lifetime labor supply. The optimum share of fertilityrelated pensions is always below unity, but generally positive. The former is true since individuals do not take into account the impact of their labor supply choice on the parent generation. It is demonstrated that child allowances are equivalent to fertility-related pensions as instruments to achieve an efficient allocation.
\end{abstract}

JEL Code: H23, H55, J13, J18.

Keywords: public pensions, pay-as-you-go, fertility, externalities.

Robert Fenge

CESifo

University of Munich \& Ifo Institute

Poschingerstrasse 5

81679 Munich

Germany

fenge@cesifo.de
Volker Meier

CESifo

University of Munich \& Ifo Institute

Poschingerstrasse 5

81679 Munich

Germany

meier@cesifo.de 


\section{Introduction}

Many existing pay-as-you-go (PAYG) systems suffer from serious financing problems. In some countries such as Italy, Japan, Germany, and Spain, fertility has fallen below the replacement level, implying that returns on contributions to the public pension system will be very low or even negative in the next decades. The construction of the PAYG system in which the active generation pays the pensions of the old generation may be blamed for this development. Since the return on social security contributions depends on average fertility in the economy, and not on individual fertility, a positive externality of having children exists. Children are necessary for a sustainable pension system, but raise the return to their parents' contributions only by a negligible fraction. Further, parents generally have to decrease their labor supply to raise children. Therefore, in a Bismarckian system, in which pensions are related to one's own contributions, the pension of parents often falls short of the pension of couples without children. Consequently, the number of children is driven down by the social security system. Empirical evidence for the negative impact of social security on fertility is presented in Cigno and Rosati (1996), and Cigno et al. (2000).

This paper addresses the question of whether and how the public pension system should be reformed so as to overcome the distortions of fertility decisions arising through a PAYG scheme. In order to keep the analysis simple, we explore a framework of a small open economy with a stationary technology. Thus, we ignore impacts of changing parameters of the PAYG pension system on growth via savings and human capital investment, which have been discussed in endogenous growth settings by Zhang (1995), Peters (1995), and Wigger (1999). Our main focus is on incentive schemes which make pensions contingent on fertility. This is done by dividing aggregate social security revenue into two components. The fraction of general pensions is paid either at a flat rate (Beveridgean type) or according to individual contributions (Bismarckian type). The remainder is spent on pensions contingent on the number of children raised by an individual. Further, we explore whether using child allowances, serving the same goal of influencing fertility, are preferable to introducing a child factor into the pension formula.

One strand of the literature on pension reforms with the aim of overcoming efficiency losses by influencing fertility, takes children as an investment good. Children may, in principle, contribute to their parents' old age income. For example, Bental (1989) assumes that each child gives an exogenous trans- 
fer to her parent. He shows that introducing public pensions proportional to the number of children can achieve Pareto optimality in a closed economy framework. In contrast, a child support will fail to realize this goal. Since the distortion is caused by the wrong level of intergenerational transfers, it has to be corrected by intergenerational transfers. Sinn (1998) stresses the function of a PAYG pension scheme as an enforcement device to ensure sufficiently high transfers from children to their parents. A collective PAYG system in which pensions are unrelated to the contributions of one's own children depresses investment in the number and quality of children. Consequently, Sinn suggests cutting pensions in proportion to the number of children that are less than optimal.

We adopt the view of the mainstream literature which considers children as a consumption good, where the number of children is an argument of the utility function. van Groezen, Leers and Meijdam (2000, 2003) analyze the option of introducing child allowances so as to internalize the externality and generate a first-best outcome. The optimum child allowance is equal to the present value of the child's contribution towards the pension scheme. This amount represents the net social gain of an additional individual given that her pension will be financed by her children (Sinn, 2001). Another plausible reform strategy is to decrease the PAYG contribution in combination with a debt policy that compensates the first generation of pensioners. But as van Groezen, Leers and Meijdam (2003) demonstrate, this reform would not be Pareto improving. This outcome is based on the results of Verbon (1988), Breyer (1989) and Fenge (1995) who have argued that this policy merely replaces the implicit debt of the PAYG scheme by an explicit public debt used for compensation. As the size of the debt does not change, the external effect of an additional child, which enlarges the tax base to serve the explicit debt, remains the same. Further, as Gaggermeier and Lucke (2002) show, although the transition to a funded system raises fertility in the steady state, it reduces the number of births on the transition path.

Kolmar (1997) takes the contribution rate to the PAYG system and the share of fertility-related pensions as policy variables. He shows that corner solutions constitute the optima. Either the PAYG scheme should be abolished or the share of fertility-related pensions should be set to unity. These results carry over to a two-country framework where individuals may migrate in order to select the preferred pension scheme (Kolmar, 2001). A similar message arises in Abio et al. (2002) who take the opportunity cost of raising children into account. They consider couples where only female labor 
supply is a choice variable. The optimal PAYG pension scheme consists in taxing male wage income and making the pension completely dependent on the number of children.

We follow Abio et al. (2002) in modelling the opportunity cost of having children. Mothers reduce their lifetime labour supply with an increasing number of children, thus losing wage income. It has been doubted whether the traditional negative relationship between fertility and female labor supply is still valid. Observations from several OECD countries during the last two decades even suggest a positive association (Ahn and Mira, 2002). However, as Kögel (2002) argues, this perceived change of signs has to be interpreted as a statistical artefact being caused by exogenous factors that simultaneously influence both fertility and labor supply decisions. Indeed, a higher fertility and an increased female labor supply can be observed at the same time during a transition period with a steadily improving supply of child care facilities. Kögel concludes that the negative association between the two has weakened during the last decades but still exists.

In contrast to the main message of the literature, we find that PAYG pensions which are completely dependent on the number of children will not be Pareto-efficient. The reason lies in the fact that a higher share of fertility-related pensions does not only stimulate fertility but also reduces labor supply per capita. The latter impact reduces social security contributions and constitutes the only relevant externality in a scheme where the full pension is contingent on the pensioner's number of children. However, it is always beneficial to introduce the child factor if the social security system is of the Bismarckian type. This result also holds for the Beveridgean flat pension type provided that fertility is relatively low.

Furthermore, if the choice is between extending the PAYG scheme by a fertility-related component and introducing family allowances, the latter yields higher welfare in situations of underinvestment, i.e. if the targeted fertility rate falls short of the interest rate. Conversely, fertility-related pensions are preferable in situations of overinvestment. This result mirrors the Aaron condition (Aaron, 1966) representing a criterion on the welfare impact of introducing PAYG pension schemes in a steady state. In contrast, if the size of the PAYG scheme is taken as given, both instruments are equivalent and can be regarded as perfect substitutes. Thus, the equivalence result of van Groezen et al. (2003) carries over to the framework with opportunity costs.

The remainder of the paper is organized as follows. Section 2 introduces 
the model. The comparative static analysis in section 3 reveals that raising the fertility-related share of pensions always increases population growth and generally reduces savings. However, savings may rise if the general pension is contribution-related such that having more children reduces an individual's income in every period. Section 4 discusses the choice of the efficient child factor in the pension scheme. Section 5 discusses the question whether fertility benefits should be paid within the pension system or, alternatively, via child allowances. Section 6 concludes and indicates directions for future research.

\section{The basic model}

We use a three-period overlapping generations model. For simplicity, we consider a one-sex population consisting of females. In period $t$ the size of the working population is $N_{t}$. The growth factor of the young generation in period $t+1$ is defined as $N_{t+1} / N_{t}=\bar{n}_{t+1}$. Note that this growth factor has to be distinguished from $n_{t+1}$, denoting the individual number of children of a household working in period $t$. These children enter the labor force in period $t+1$. A generation lives for three periods. In the first period, an individual lives with her parent, where necessary expenses are part of her parent's consumption. Introducing direct costs of children would complicate the notation without affecting the main results. Clearly, direct costs of children are never a source of an externality.

In the second period, the household works, earns a wage rate $w_{t}$ and decides how much to save, $s_{t}$, and to consume, $c_{t}$. Moreover, the household chooses the number of children, $n_{t+1}$, that she will have in this period. In order to simplify the analysis, $n_{t+1}$ can be chosen from the set of non-negative real numbers. Children increase the utility of the household, but also reduce opportunities for earning wage income. We consider the loss in labour time due to rearing children as the primary cost of having offspring. The reduction of wage income is assumed to increase at least proportionally with the number of children. Wage income is then given by $\left[1-f\left(n_{t+1}\right)\right] w_{t}$ with $f(0)=0$, $f^{\prime}\left(n_{t+1}\right)>0$ and $f^{\prime \prime}\left(n_{t+1}\right) \geq 0$. Though this specification of labor supply is clearly unreasonable for higher numbers of children, it reflects observable patterns of families with up to three children. Furthermore, in the second period the household has to pay contributions to the PAYG pension system where the contribution rate is $\tau_{t}$. 


$$
c_{t}+s_{t}=\left(1-\tau_{t}\right)\left[1-f\left(n_{t+1}\right)\right] w_{t} .
$$

In the third period the household retires and consumes $z_{t+1}$. Old age consumption equals the sum of private savings multiplied by the interest factor $R_{t+1}$, and the pension $p_{t+1}$.

$$
z_{t+1}=R_{t+1} s_{t}+p_{t+1}
$$

The utility function of the household $U\left(c_{t}, z_{t+1}, n_{t+1}\right)$ is continuous, strictly increasing in all three arguments and strictly concave. In order to keep the notation simple, we assume the utility function to exhibit additive seperability. Hence, the cross derivatives of the utility function are zero: $U_{12}=U_{21}=$ $U_{23}=U_{32}=U_{13}=U_{31}=0$.

The government runs a PAYG financed pension scheme. The contribution revenues in period $t+1$ are used to finance the pension $p_{t+1}$ of the $N_{t}$ retirees of generation $t$. The pension of a household depends, with a share $\alpha$ of the contributions, on the number of children of the household and, with a share $1-\alpha$, on the aggregate growth factor of the population. In the following we call the policy variable $\alpha$ the child factor. The pension of an individual is given by

$$
p_{t+1}=\tau_{t+1} w_{t+1}\left(1-\tilde{f}\left(\eta_{t+2}\right)\right)\left[(1-\alpha) \bar{n}_{t+1} \frac{1-f\left(n_{t+1}\right)}{1-\tilde{f}\left(\eta_{t+1}\right)}+\alpha n_{t+1}\right],
$$

where $\eta_{t+1}$ refers to the distribution of fertility rates in generation $t$, and $1-\tilde{f}\left(\eta_{t+1}\right)$ denotes labor supply per capita of the individuals working in period $t$. Of course, as long as all individuals within a generation are identical, we have $\tilde{f}\left(\eta_{t+1}\right)=f\left(n_{t+1}\right)$. Note that $\tau_{t+1} w_{t+1}\left(1-\tilde{f}\left(\eta_{t+2}\right)\right)$ is the average contribution of an individual working in period $t+1$. The parent collects the share $\alpha$ of the contributions of her $n_{t+1}$ children. The remainder is spent in the general scheme in which $\bar{n}_{t+1}$ contributors finance one pensioner. In a Bismarckian system, the pension fund is distributed according to contributions, being expressed by the factor $\frac{1-f\left(n_{t+1}\right)}{1-\tilde{f}\left(\eta_{t+1}\right)}$. Under a flat pension system of the Beveridge type, the corresponding factor would always be unity. In a Bismarckian PAYG system without a child factor $(\alpha=0)$ the pension of a household decreases with more children due to the declining contributions. 
Inserting (1)-(3) into the utility function yields the maximization problem

$$
\begin{aligned}
& \underset{s_{t}, n_{t+1}}{\operatorname{Max}} U\left\{\left(1-\tau_{t}\right)\left[1-f\left(n_{t+1}\right)\right] w_{t}-s_{t},\right. \\
& R_{t+1} s_{t}+\tau_{t+1} w_{t+1}\left(1-\tilde{f}\left(\eta_{t+2}\right)\right) \\
& \left.\cdot\left[(1-\alpha) \bar{n}_{t+1} \frac{1-f\left(n_{t+1}\right)}{1-\tilde{f}\left(\eta_{t+1}\right)}+\alpha n_{t+1}\right], n_{t+1}\right\} .
\end{aligned}
$$

We assume that an interior solution to this problem exists. The economy is large in the sense that the individual ignores the impact of her fertility decision on average fertility and labor supply per capita in the country. The first-order conditions determine the household's optimal decisions:

$$
\begin{gathered}
U_{s}=-U_{1}+R_{t+1} U_{2}=0 \\
U_{n}=-U_{1}\left(1-\tau_{t}\right) w_{t} f^{\prime}\left(n_{t+1}\right)+U_{2} \frac{\partial p_{t+1}}{\partial n_{t+1}}+U_{3}=0
\end{gathered}
$$

with $\frac{\partial p_{t+1}}{\partial n_{t+1}}=\tau_{t+1} w_{t+1}\left(1-\tilde{f}\left(\eta_{t+2}\right)\right)\left[\alpha-(1-\alpha) \bar{n}_{t+1} \frac{f^{\prime}\left(n_{t+1}\right)}{1-\tilde{f}\left(\eta_{t+1}\right)}\right]$ in a Bismarckian system whereas $\frac{\partial p_{t+1}}{\partial n_{t+1}}=\tau_{t+1} w_{t+1}\left(1-\tilde{f}\left(\eta_{t+2}\right)\right) \alpha$ if a Beveridge scheme is in place. The partial derivative of $U$ with respect to its $i^{\text {th }}$ argument is denoted by $U_{i}$, while the derivatives with respect to the optimization variables are represented by $U_{s}=\frac{\partial U}{\partial s_{t}}$ and $U_{n}=\frac{\partial U}{\partial n_{t+1}}$. As demonstrated in the appendix, the objective function is strictly concave in the decision variables both under the Bismarckian and under the Beveridgean scheme, ensuring uniqueness of the maximum.

The optimality condition (6) can be interpreted as follows. The marginal disutility of children, resulting from a lower wage income and - under a Bismarckian regime - a reduced contribution-related pension, is equal to the sum of the direct marginal benefit of having children and the gain due to a higher fertility-related pension.

\section{Comparative statics}

Proposition 1 describes how saving and fertility of a household react to a rising child factor of the pension system. It turns out that fertility always 
increases. The expected fall in savings depends on a condition with respect to the substitutability of children and savings. This condition is not necessarily satisfied if a Bismarckian pension system is in place.

Proposition 1 Fertility increases with a higher child factor in the pension system. Savings decrease with a higher child factor in the pension system if, and only if, savings and children are substitutes, i.e. $U_{s n}<0$.

Proof. Applying the implicit function theorem to the set of first-order conditions (5) and (6) leads to

$$
\frac{\partial n}{\partial \alpha}=-\frac{\operatorname{det}\left[\begin{array}{cc}
U_{s s} & U_{s \alpha} \\
U_{n s} & U_{n \alpha}
\end{array}\right]}{\operatorname{det}\left[\begin{array}{ll}
U_{s s} & U_{s n} \\
U_{n s} & U_{n n}
\end{array}\right]}
$$

with

$$
\begin{aligned}
U_{s \alpha}= & U_{22} R_{t+1} \tau_{t+1} w_{t+1}\left(1-\tilde{f}\left(\eta_{t+2}\right)\left[n_{t+1}-\bar{n}_{t+1} \frac{1-f\left(n_{t+1}\right)}{1-\tilde{f}\left(\eta_{t+1}\right)}\right],\right. \\
U_{n \alpha}= & U_{2} \tau_{t+1} w_{t+1}\left(1-\tilde{f}\left(\eta_{t+2}\right)\right)\left[1+\bar{n}_{t+1} \frac{f^{\prime}\left(n_{t+1}\right)}{1-\tilde{f}\left(\eta_{t+1}\right)}\right] \\
+ & U_{22} \tau_{t+1}^{2} w_{t+1}^{2}\left(1-\tilde{f}\left(\eta_{t+2}\right)\right)^{2} \\
& \cdot\left[n_{t+1}-\bar{n}_{t+1} \frac{1-f\left(n_{t+1}\right)}{1-\tilde{f}\left(\eta_{t+1}\right)}\right]\left[\alpha-(1-\alpha) \bar{n}_{t+1} \frac{f^{\prime}\left(n_{t+1}\right)}{1-\tilde{f}\left(\eta_{t+1}\right)}\right] \\
U_{n s}= & U_{11}\left(1-\tau_{t}\right) w_{t} f^{\prime}\left(n_{t+1}\right)+U_{22} R_{t+1} \tau_{t+1} w_{t+1}\left(1-\tilde{f}\left(\eta_{t+2}\right)\right) \\
& \cdot\left[\alpha-(1-\alpha) \bar{n}_{t+1} \frac{f^{\prime}\left(n_{t+1}\right)}{1-\tilde{f}\left(\eta_{t+1}\right)}\right]
\end{aligned}
$$

under a Bismarckian scheme and

$$
U_{s \alpha}=U_{22} R_{t+1} \tau_{t+1} w_{t+1}\left(1-\tilde{f}\left(\eta_{t+2}\right)\left[n_{t+1}-\bar{n}_{t+1}\right]\right.
$$




$$
\begin{gathered}
\begin{aligned}
& U_{n \alpha}= U_{2} \tau_{t+1} w_{t+1}\left(1-\tilde{f}\left(\eta_{t+2}\right)\right) \\
&+U_{22} \tau_{t+1}^{2} w_{t+1}^{2}\left(1-\tilde{f}\left(\eta_{t+2}\right)\right)^{2}\left[n_{t+1}-\bar{n}_{t+1}\right] \alpha \\
& U_{n s}=U_{11}\left(1-\tau_{t}\right) w_{t} f^{\prime}\left(n_{t+1}\right)+U_{22} R_{t+1} \tau_{t+1} w_{t+1}\left(1-\tilde{f}\left(\eta_{t+2}\right)\right) \alpha
\end{aligned}
\end{gathered}
$$

if the general pension is of the Beveridge type.

The denominator of the RHS equation (7) has a positive sign due to the strict concavity of the utility function with respect to the decision variables. In a homogenous population with a representative household in each generation $n_{t}=\bar{n}_{t}$ holds in equilibrium. Hence, $U_{s \alpha}=0$ and $U_{n \alpha}>0$ are valid under each regime. With a positive sign of the determinant in the numerator of (7) we conclude that $\frac{\partial n}{\partial \alpha}>0$.

The derivative of savings with respect to $\alpha$ is given by

$$
\frac{\partial s}{\partial \alpha}=-\frac{\operatorname{det}\left[\begin{array}{cc}
U_{s \alpha} & U_{s n} \\
U_{n \alpha} & U_{n n}
\end{array}\right]}{\operatorname{det}\left[\begin{array}{cc}
U_{s s} & U_{s n} \\
U_{n s} & U_{n n}
\end{array}\right]}
$$

The property $U_{n s}<0$ is then obviously necessary and sufficient to establish $\frac{\partial s}{\partial \alpha}<0$.

The intuition for the results is straightforward. A higher child factor changes the structure of the pension income in favor of the child-related component. This increases the marginal benefit of having children, yielding a higher fertility level. Having more children means that labour supply has to be reduced. Under a Beveridge regime, where the condition $U_{n s}<0$ is always met, the fall in wage income is partially offset by lower savings. In a Bismarck scheme, the individual will also face a reduction of contributionrelated pension claims if she reduces her labor supply. Should these losses exceed the gains in the fertility-related pensions, a situation which would be described by $\left[\alpha-(1-\alpha) \bar{n}_{t+1} \frac{f^{\prime}\left(n_{t+1}\right)}{1-\tilde{f}\left(\eta_{t+1}\right)}\right]<0$, it may well be the case that an individual responds to a higher child factor by increasing her savings. 


\section{Efficiency}

A central question is now whether the households can be made better off by increasing the child factor of the pension system. In the representative agent framework one is tempted to assume that increasing the child factor to unity eliminates all externalities associated with having children. This suspicion is wrong.

Proposition 2 The efficient child factor $\alpha^{*}$ is always smaller than unity.

Proof. The indirect utility function under a Bismarckian scheme is given by

$$
\begin{aligned}
V(\alpha)= & U\left\{\left(1-\tau_{t}\right)\left[1-f\left(n_{t+1}(\alpha)\right)\right] w_{t}-s_{t}(\alpha), R_{t+1} s_{t}(\alpha)\right. \\
& +\tau_{t+1} w_{t+1}\left(1-\tilde{f}\left(\eta_{t+2}\right)(\alpha)\right)\left[(1-\alpha) \bar{n}_{t+1}(\alpha) \frac{1-f\left(n_{t+1}\right)(\alpha)}{1-\tilde{f}\left(\eta_{t+1}\right)(\alpha)}\right. \\
& \left.\left.+\alpha n_{t+1}(\alpha)\right], n_{t+1}(\alpha)\right\}
\end{aligned}
$$

where the factor $\frac{1-f\left(n_{t+1}\right)(\alpha)}{1-\tilde{f}\left(\eta_{t+1}\right)(\alpha)}$ would be replaced by 1 under a Beveridgean rule.

Employing the envelope theorem, the derivation with respect to $\alpha$ yields, after rearranging:

$$
\begin{aligned}
\frac{d V_{B i s}}{d \alpha}= & U_{2} \tau_{t+1} w_{t+1}\left\{\left(1-\tilde{f}\left(\eta_{t+2}\right)\right)\left[n_{t+1}-\bar{n}_{t+1} \frac{1-f\left(n_{t+1}\right)}{1-\tilde{f}\left(\eta_{t+1}\right)}\right]\right. \\
& -\frac{\partial \tilde{f}\left(\eta_{t+2}\right)}{\partial \alpha}\left[(1-\alpha) \bar{n}_{t+1} \frac{1-f\left(n_{t+1}\right)}{1-\tilde{f}\left(\eta_{t+1}\right)}+\alpha n_{t+1}\right] \\
& +\left(1-\tilde{f}\left(\eta_{t+2}\right)\right)(1-\alpha) \bar{n}_{t+1} \frac{1-f\left(n_{t+1}\right)}{\left[1-\tilde{f}\left(\eta_{t+1}\right)\right]^{2}} \frac{\partial \tilde{f}\left(\eta_{t+1}\right)}{\partial \alpha} \\
& \left.+(1-\alpha)\left(1-\tilde{f}\left(\eta_{t+2}\right)\right) \frac{\partial \bar{n}_{t+1}}{\partial \alpha} \frac{1-f\left(n_{t+1}\right)}{1-\tilde{f}\left(\eta_{t+1}\right)}\right\},
\end{aligned}
$$


and

$$
\begin{aligned}
\frac{d V_{\text {Bev }}}{d \alpha}= & U_{2} \tau_{t+1} w_{t+1}\left\{\left(1-\tilde{f}\left(\eta_{t+2}\right)\right)\left[n_{t+1}-\bar{n}_{t+1}\right]\right. \\
& -\frac{\partial \tilde{f}\left(\eta_{t+2}\right)}{\partial \alpha}\left[(1-\alpha) \bar{n}_{t+1}+\alpha n_{t+1}\right] \\
& \left.+(1-\alpha)\left(1-\tilde{f}\left(\eta_{t+2}\right)\right) \frac{\partial \bar{n}_{t+1}}{\partial \alpha}\right\}
\end{aligned}
$$

In the simple case of homogenous households the aggregate population growth factor is identical to the individual fertility factor: $\overline{n_{t}}=n_{t}$ in the equilibrium. Hence,

$$
\frac{d V}{d \alpha}(\alpha=1)=-U_{2} \tau_{t+1} w_{t+1} \bar{n}_{t+1} \frac{\partial \tilde{f}\left(\eta_{t+2}\right)}{\partial \alpha}<0
$$

because $\frac{\partial n_{t+1}}{\partial \alpha}>0$ and $f^{\prime}>0$.

The result can be explained as follows. First, the increasing child factor changes the weights of the contribution-related pension and the fertilityrelated pension. Since individuals have the same number of children, the net effect of changing the composition is zero, as expressed by $U_{2} \tau_{t+1} w_{t+1}(1-$ $\left.\tilde{f}\left(\eta_{t+2}\right)\right)\left[n_{t+1}-\bar{n}_{t+1} \frac{1-f\left(n_{t+1}\right)}{1-\tilde{f}\left(\eta_{t+1}\right)}\right]=0$.

Second, increasing the child factor has a negative impact on utility because the increasing number of children calls for more time to care for these children. This reduces the labor supply and, hence, the wage income of the next contributor generation. Consequently, there are less means to finance the pensions of the present generation. The lower pensions reduce welfare, as shown by $-U_{2} \tau_{t+1} w_{t+1} \frac{\partial \tilde{f}\left(\eta_{t+2}\right)}{\partial \alpha}\left[(1-\alpha) \bar{n}_{t+1} \frac{1-f\left(n_{t+1}\right)}{1-\tilde{f}\left(\eta_{t+1}\right)}+\alpha n_{t+1}\right]<0$.

Third, an effect arising only in the Bismarckian scheme, but not in the Beveridge system, the general pension rises at a given pension fund level because of lower claims by other people due to their reduced labor supply. This impact is captured by $U_{2} \tau_{t+1} w_{t+1}\left(1-\tilde{f}\left(\eta_{t+2}\right)\right)(1-\alpha) \bar{n}_{t+1} \frac{1-f\left(n_{t+1}\right)}{\left[1-\tilde{f}\left(\eta_{t+1}\right)\right]^{2}} \frac{\partial \tilde{f}\left(\eta_{t+1}\right)}{\partial \alpha}>0$.

Fourth, a higher child factor increases the number of future contributors to the general PAYG pension system and, therefore, the rate of return of the system. This raises the utility of the present generation, as shown by 
$U_{2} \tau_{t+1} w_{t+1}(1-\alpha)\left(1-\tilde{f}\left(\eta_{t+2}\right)\right) \frac{\partial \bar{n}_{t+1}}{\partial \alpha} \frac{1-f\left(n_{t+1}\right)}{1-\tilde{f}\left(\eta_{t+1}\right)}>0$. Since only the second effect survives if the share of general public pensions tends to zero, only the negative impact remains at $\alpha=1$.

An increase of the child factor is associated with more heads of the future generation, raising the return to general social security contributions, but less wage income per head, reducing the return in both branches of the public pension system.

The child component can be used to reduce the intra-generational externality, where the gains accrue to the pensions related to contributions. If the share of these general pensions becomes small, the impact on welfare will also be reduced. At the same time, the inter-generational externality, caused by children reducing working hours without taking into account the fall in their parents' pensions, cannot be overcome.

Given that we have a stationary sequence $\left\{\tau_{t}, \alpha_{t}, w_{t}, R_{t}\right\}$, the fertility rates remain constant over time. If we consider a Bismarckian system with a permanent variation in $\alpha$, we have

$$
\frac{d V_{B i s}}{d \alpha}(\alpha=0)=U_{2} \tau w \frac{\partial n}{\partial \alpha}[1-f(n)]>0 .
$$

In a steady state where fertility-related pensions are absent, two externalities from raising the child factor just offset each other. The negative externality due to a reduced labor supply per capita of the next generation cancels out against the positive externality from increasing the pension claim due to a lower labor supply of the other individuals in the current generation. The net impact on welfare is therefore given by the higher return to contributions caused by the increasing number of heads in the next generation.

It should be noted that the last result does not necessarily carry over to a Beveridge scheme. Since the positive externality stemming from a redistribution of claims within a generation does not exist, we would have

$$
\frac{d V_{B e v}}{d \alpha}(\alpha=0)=U_{2} \tau w \frac{\partial n}{\partial \alpha}\left[1-f(n)-n f^{\prime}(n)\right] .
$$

Should preferences for children be very strong, it cannot be excluded that $1-f(n)-n f^{\prime}(n)<0$. However, if preferences for children are relatively weak, as seems to be the case nowadays in many European countries, introducing a child factor into the pension formula is beneficial. A positive child factor is particularly likely if fertility is very low without the child component $\left(\bar{n}_{t+1}\right.$ 
small at $\alpha=0$ ), and, in addition, the reduction of labor supply due to a higher number of children is not very sharp $\left(f^{\prime}\right.$ small). Since both conditions tend to be satisfied in countries suffering most from the ageing process, their governments may be well advised to introduce a child factor in the pension formula. In contrast, should fertility already be high without having a child factor within a Beveridgean system, the optimum consists in setting this factor to zero.

In case of an interior solution the efficient child factor $\alpha^{*}$ would have to satisfy the condition

$$
\alpha_{B i s}^{*}=\frac{1-f\left(n\left(\alpha^{*}\right)\right)}{1-f\left(n\left(\alpha^{*}\right)\right)+n\left(\alpha^{*}\right) f^{\prime}\left(n\left(\alpha^{*}\right)\right)}
$$

in a Bismarckian scheme and

$$
\alpha_{\text {Bev }}^{*}=1-\frac{n\left(\alpha^{*}\right) f^{\prime}\left(n\left(\alpha^{*}\right)\right)}{1-f\left(n\left(\alpha^{*}\right)\right)}
$$

if the pension formula is of the Beveridgean type. In either case, the RHS decreases in $\alpha$ while the LHS increases in $\alpha$. Thus, $\alpha^{*}$ is unique. Further, there is a clear tendency that a higher $n(0)$ reduces $\alpha^{*}$. Hence, the higher the fertility level without intervention is, the smaller the optimum child factor in the pension formula will be.

\section{Child factor versus family allowances}

An interesting issue to explore is whether or not family allowances can be constructed in such a fashion that a Pareto improvement is achieved compared to introducing the optimum child factor in the pension formula. Family allowances may give the same fertility incentive as the optimum child factor. At the same time, individuals may enjoy a higher lifetime income by saving in the capital market rather than contributing to the PAYG-scheme.

As before, both pensions and fertility related benefits are financed by a payroll tax. As an alternative to a pension system with contributrion rate $\tau$ and a child factor $\alpha$, we consider a pension scheme without fertility-related benefits in combination with a child allowance system. Let the pension contribution rate in this framework be $\theta^{P}$, while the contribution rate towards the family allowance system amounts to $\theta^{F}$. Parents receive the family allowance $\pi_{t}$ for every child born in period $t$. The budget equation for an 
individual in the working period reads

$$
c_{t}+s_{t}=\left(1-\theta_{t}^{P}-\theta_{t}^{F}\right)\left[1-f\left(n_{t+1}\right)\right] w_{t}+\pi_{t} n_{t+1} .
$$

As before, second period consumption is $z_{t}=R_{t+1} s_{t}+p_{t+1}$. We restrict our attention to Bismarckian pension schemes. Pensions are financed according to

$$
p_{t+1}=\theta_{t+1}^{P} w_{t+1}\left(1-\tilde{f}\left(\eta_{t+2}\right)\right) \bar{n}_{t+1} \frac{1-f\left(n_{t+1}\right)}{1-\tilde{f}\left(\eta_{t+1}\right)},
$$

while the family allowance satisfies the budget equation

$$
\pi_{t} \bar{n}_{t+1}=\theta_{t}^{F} w_{t}\left[1-\tilde{f}\left(\eta_{t+1}\right)\right] .
$$

Individual decisions on savings and fertility levels yield the first-order conditions

$$
\begin{gathered}
U_{s}=-U_{1}+R_{t+1} U_{2}=0 \\
U_{n}=U_{1}\left[\pi_{t}-\left(1-\theta_{t}^{P}-\theta_{t}^{F}\right) w_{t} f^{\prime}\left(n_{t+1}\right)\right]+U_{2} \frac{\partial p_{t+1}}{\partial n_{t+1}}+U_{3}=0,
\end{gathered}
$$

with $\frac{\partial p_{t+1}}{\partial n_{t+1}}=-\theta_{t+1}^{P} w_{t+1}\left(1-\tilde{f}\left(\eta_{t+2}\right)\right) \bar{n}_{t+1} \frac{f^{\prime}\left(n_{t+1}\right)}{1-\tilde{f}\left(\eta_{t+2}\right)}<0$. Fertility is chosen in such a way that the marginal benefit due to the direct effect via $U_{3}$ and the family allowance is equal to the cost due to a lower income in the first period and the reduced pension claims due to lower contributions of the next generation.

Proposition 3 describes the steady-state perspective for the situation in which the contribution rate towards the general pension scheme is fixed. A family allowance system is compared to the extension of the PAYG system by a fertility-related component. As expected, the decisive question is whether or not the interest factor exceeds the fertility rate.

Proposition 3 If the optimum child factor in the pension formula yields a fertility rate expressing underinvestment $(n<R)$, welfare is higher when using family allowances rather than the child factor. Conversely, should the optimum family allowance be associated with a situation of overinvestment $(n>R)$, the optimum child factor dominates the optimum family allowance. 
Proof. Suppose that the optimum child factor $\alpha^{*}$ will be associated with $R>n$. Consider now a system with family allowances where $\tau=\theta^{P}+\theta^{F}$ and $\theta^{F}=\alpha^{*} \tau$. If the family allowance is set to $\pi=\frac{1}{R} \theta^{F} w_{t}\left[1-\tilde{f}\left(\eta_{t+1}\right)\right]$, all individuals will choose the same number of children as under the optimum child factor, while savings would satisfy $s=s\left(\alpha^{*}\right)+n \pi$. At the same time, a family allowance budget surplus has been created which can be used to raise welfare.

Conversely, let the optimum family allowance scheme $\left(\theta^{F *}, \pi^{*}\right)$ be associated with $R<n$. Consider now a system with a child factor in the pension formula where $\tau=\theta^{P}+\theta^{F *}$ and $(1-\alpha) \tau=\theta^{P}$. If the fertility-related pension is set to $R \pi^{*}$ per child, all individuals will choose the same number of children as under the optimum family allowance, while savings would satisfy $s=s\left(\pi^{*}\right)-n \pi$. At the same time, a budget surplus in the pension scheme has been created which can be used to increase welfare.

The proposition points to the fact that family allowances and fertilityrelated pensions are imperfect substitutes if we have a given value of flat or contribution-related pensions. It states that only one of the two instruments should be used. If the target fertility rate is below the interest factor, the government can rely exclusively on family allowances. Granting the fertility benefit as a pension is a waste of resources because the return to contributions in the PAYG scheme falls short of the interest rate. The steady-state perspective would then also call for abolishing the PAYG pension. In fact, the proposition has to be traced back to the fact that we compare two PAYG systems of different size, where the result is obtained by applying the wellknown Aaron condition (Aaron, 1966). However, the argument is not valid for transition paths. The message from the literature on Pareto improving: transitions by abolishing PAYG pensions is as follows. A Pareto improving transition is impossible if the pension system displays no distortions of incentives. In the opposite case, reducing distortions is a source of welfare gains. Yet, all Pareto improvements can be achieved by getting rid of the distortions while keeping the PAYG scheme intact (Fenge, 1995).

If the target fertility level yields overinvestment, extending the PAYG scheme by a fertility related pension dominates the family allowance. A conceivable justification for the family allowance under these circumstances would lie in possibly existing liquidity constraints of young parents.

Consider now the problem where the size of the PAYG scheme is given. Thus, $\tau=\theta_{P}$ is fixed, while $\alpha$ and $\theta_{F}$ are the policy variables. The govern- 
ment maximizes

$$
\begin{aligned}
& U\left(\left(1-\tau-\theta_{F}\right)\left(1-f\left(n_{t+1}\right)\right) w+\theta_{F} \frac{n_{t+1} w}{\bar{n}_{t+1}}\left[1-\tilde{f}\left(\eta_{t+1}\right)\right]-s,\right. \\
& \left.R s+\tau w\left[1-\tilde{f}\left(\eta_{t+2}\right)\right]\left[(1-\alpha) \bar{n}_{t+1} \frac{1-f\left(n_{t+1}\right)}{1-\tilde{f}\left(\eta_{t+1}\right)}+\alpha n_{t+1}\right], n_{t+1}\right)
\end{aligned}
$$

with respect to $\alpha$ and $\theta_{F}$ subject to $\alpha \geq 0$ and $\theta_{F} \geq 0$.

Obviously, the impacts of raising the family allowance tax are quite similar to the consequences of a higher share of fertility-related pensions. In fact, Proposition 4 shows that both instruments are equivalent. Welfare can be maximized by using either only the pension factor or only child allowances or a combination of both. The proof is given only for the Bismarckian pension system, but can easily be transposed to a Beveridgean scheme provided that fertility incentives in the optimum are positive.

Proposition 4 The optimum allocation $\left(c_{t}^{*}, z_{t+1}^{*}, n_{t+1}^{*}\right)$ can be achieved both with a combination of the child factor and the family allowance and an exclusive use of only one instrument.

Proof. Notice that the individual decisions under a Bismarckian pension scheme are determined by the first-order conditions

$$
\begin{aligned}
U_{s}= & -U_{1}+R_{t+1} U_{2}=0 \\
U_{n}= & U_{1}\left[\frac{\theta_{F}\left(1-\tilde{f}\left(\eta_{t+1}\right)\right) w_{t}}{\bar{n}_{t+1}}-\left[1-\tau_{t}-\theta_{F}\right] f^{\prime}\left(n_{t+1}\right) w_{t}\right] \\
& +U_{2} \tau_{t+1} w_{t+1}\left(1-\tilde{f}\left(\eta_{t+2}\right)\right)\left[\alpha-(1-\alpha) \frac{f^{\prime}\left(n_{t+1}\right)}{\left(1-\tilde{f}\left(\eta_{t+1}\right)\right)} \bar{n}_{t+1}\right]+U_{3} \\
= & 0 .
\end{aligned}
$$

Now suppose that a combination $\left(\alpha^{*}, \theta_{F}^{*}\right)>0$ maximizes utility, yielding a vector of consumption and fertility $\left(c_{t}^{*}, z_{t+1}^{*}, n_{t+1}^{*}\right)$ where savings are $s^{*}$. Consider an alternative combination $\left(\alpha^{0}, \theta_{F}^{0}\right)$ with $\alpha^{0}, \theta_{F}^{0} \geq 0$ satisfying the 
condition

$$
\begin{aligned}
& R_{t+1}\left[\frac{\theta_{F}^{0}\left(1-f\left(n_{t+1}^{*}\right)\right) w_{t}}{n_{t+1}^{*}}-\left[1-\tau_{t}-\theta_{F}^{0}\right] f^{\prime}\left(n_{t+1}^{*}\right) w_{t}\right] \\
+ & \tau_{t+1} w_{t+1}\left(1-f\left(n_{t+2}^{*}\right)\right)\left[\alpha^{0}-\left(1-\alpha^{0}\right) \frac{f^{\prime}\left(n_{t+1}^{*}\right)}{\left(1-f\left(n_{t+1}^{*}\right)\right)} n_{t+1}^{*}\right] \\
= & -\frac{U_{3}\left(n_{t+1}^{*}\right)}{U_{2}\left(z_{t+1}^{*}\right)}
\end{aligned}
$$

with $n_{t+1}^{*}=n_{t+2}^{*}$. An inspection of the optimality conditions reveals that $\left(s^{*}, n_{t+1}^{*}\right)$ also fulfills the equations $(22)$ and $(23)$ for the parameters $\left(\alpha^{\mathbf{0}}, \theta_{F}^{\mathbf{0}}\right)$, generating the vector $\left(c_{t}^{*}, z_{t+1}^{*}, n_{t+1}^{*}\right)$. Further, equation (24) defines a function $\theta_{F}^{0}\left(\alpha^{0}\right)$ with $\frac{d \theta_{F}^{0}}{d \alpha^{0}}<0$. For $\alpha^{0}=0$, the corresponding child allowance tax rate is

$$
\left.\theta_{F}^{0}\right|_{\alpha^{0}=0}=\frac{R_{t+1}\left[1-\tau_{t}\right] f^{\prime}\left(n_{t+1}^{*}\right) w_{t}+\tau_{t+1} w_{t+1} f^{\prime}\left(n_{t+1}^{*}\right) n_{t+1}^{*}-\frac{U_{3}\left(n_{t+1}^{*}\right)}{U_{2}\left(z_{t+1}^{*}\right)}}{R_{t+1} w_{t}\left[\frac{\left(1-f\left(n_{t+1}^{*}\right)\right)}{n_{t+1}^{*}}+f^{\prime}\left(n_{t+1}^{*}\right)\right]}
$$

Conversely, for $\theta_{F}^{0}=0$, the corresponding child factor is

$$
\left.\alpha^{0}\right|_{\theta_{F}^{0}=0}=\frac{R_{t+1}\left[1-\tau_{t}\right] f^{\prime}\left(n_{t+1}^{*}\right) w_{t}+\tau_{t+1} w_{t+1} f^{\prime}\left(n_{t+1}^{*}\right) n_{t+1}^{*}-\frac{U_{3}\left(n_{t+1}^{*}\right)}{U_{2}\left(z_{t+1}^{*}\right)}}{\tau_{t+1} w_{t+1}\left(1-f\left(n_{t+2}^{*}\right)\right)\left[1+\frac{f^{\prime}\left(n_{t+1}^{*}\right)}{\left(1-f\left(n_{t+1}^{*}\right)\right)} n_{t+1}^{*}\right]}
$$

Since $\left(\alpha^{*}, \theta_{F}^{*}\right)>0$ and $\frac{d \theta_{F}^{0}}{d \alpha^{0}}<0$, it follows that $\left.\theta_{F}^{0}\right|_{\alpha^{0}=\mathbf{0}}>0$ and $\left.\alpha^{0}\right|_{\theta_{F}^{0}=0}>0$.

The proposition is easily understood. Both family allowances and the child factor affect the savings decision only via influencing the fertility rate and only by redistributing resources within a generation. The same fertility rate at given levels of $\tau, w$, and $R$ will yield an identical savings decision. Therefore, both instruments will lead to the same utility level. In this sense, they can be described as "Siamese twins" (van Groezen et al. (2003)). Moreover, a continuum of optima exists where both instruments are varied 
against each other. Given that family allowances are easier to administer and have the advantage of alleviating liquidity constraints of young families, this implies an advantage for family allowances in practice.

The equivalence result will presumably no longer hold if the labor supply decision and the fertility decision are not tied to each other as in our framework. For example, only maximum labor supply may be a function of fertility while leisure enters the utility function as an additional argument. At a given contribution rate towards a Beveridgean pension system, the tax on labor is higher if family allowances are paid than under fertility-related pensions. Thus, if disincentives with respect to labor supply are of importance, modifying the pension formula for setting fertility incentives can be preferable to extending an existing family allowance system.

\section{Conclusions}

The main message of this study is that the positive externality of having children for PAYG pension schemes should not be internalized by making the pension completely dependent on fertility. The reason for this result lies in the fact that introducing a child factor in social security intensifies an important intergenerational problem. Individuals do not take into account the impact of their labor supply decision, which is closely linked to their fertility choice, on the wellbeing of the parent generation. Moreover, the analysis indicates that the optimum fertility rate can either be achieved by introducing a child factor in pension formula or by implementing a system of child allowances. Fxtending the PAYG scheme by fertility-related pensions is associated with a serious disadvantage compared to child allowances in countries in which fertility will be low even after introducing fertility enhancing policies. Should the rate of return in the general PAYG scheme fall short of the interest rate, encouraging fertility by a child factor in the pension formula rather than simply using family allowances is a waste of resources. This view is no longer relevant if transition problems are taken into account where it is impossible to cut the pension tax in a Pareto improving fashion.

An interesting extension of the current analysis would be to drop the assumption of a small open economy. Given that many industrialized countries are confronted with the question of how to reform the pension so as to change the fertility pattern, tackling the problem addressed here in a framework with endogenous factor prices is of interest. Cigno (1993) has already pointed out 
that the distortion of fertility decisions induced by the PAYG pension scheme looks quite different in a closed economy or in a large open economy. The policy of investing in the world capital market at an unchanged interest rate and letting foreigners bear the cost of raising the next generation is feasible only for people living in a small open economy.

Further, distributional aspects within generations have not been discussed. Introducing heterogeneity in fertility would imply that individuals are affected by policy measures encouraging fertility in an asymmetric fashion. It may then be asked under which circumstances a Pareto improvement is created without additional redistributive measures, and how such measures should be designed if there is a conflict of interest between childless individuals and parents. Incorporating both endogenous factor prices and heterogeneity in fertility would make it possible that childless people who are subsidizing others in a family allowance system are compensated by an increase in the interest rate in the economy, as in Felderer and Ritzberger (1995).

\section{Appendix}

\section{Concavity of the objective function}

Notice that

$$
U_{s s}=U_{11}+R_{t+1}^{2} U_{22}<0 .
$$

For the Bismarckian pension scheme it follows that

$$
\begin{aligned}
U_{n n}= & -U_{1}\left(1-\tau_{t}\right) w_{t} f^{\prime \prime}\left(n_{t+1}\right)+U_{11}\left(1-\tau_{t}\right)^{2} w_{t}^{2}\left[f^{\prime}\left(n_{t+1}\right)\right]^{2} \\
& -U_{2} \tau_{t+1} w_{t+1}\left(1-\tilde{f}\left(\eta_{t+2}\right)\right)(1-\alpha) \bar{n}_{t+1} \frac{f^{\prime \prime}\left(n_{t+1}\right)}{1-\tilde{f}\left(\eta_{t+1}\right)} \\
& +U_{22} \tau_{t+1}^{2} w_{t+1}^{2}\left(1-\tilde{f}\left(\eta_{t+2}\right)\right)^{2}\left[\alpha-(1-\alpha) \bar{n}_{t+1} \frac{f^{\prime}\left(n_{t+1}\right)}{1-\tilde{f}\left(\eta_{t+1}\right)}\right]^{2} \\
& +U_{33} \\
< & 0,
\end{aligned}
$$




$$
\begin{aligned}
& U_{s s} U_{n n}-U_{n s} U_{s n}=\left[U_{11}+R_{t+1}^{2} U_{22}\right]\left[-U_{1}\left(1-\tau_{t}\right) w_{t} f^{\prime \prime}\left(n_{t+1}\right)\right. \\
& +U_{11}\left(1-\tau_{t}\right)^{2} w_{t}^{2}\left[f^{\prime}\left(n_{t+1}\right)\right]^{2} \\
& -U_{2} \tau_{t+1} w_{t+1}\left(1-\tilde{f}\left(\eta_{t+2}\right)\right)(1-\alpha) \bar{n}_{t+1} \frac{f^{\prime \prime}\left(n_{t+1}\right)}{1-\tilde{f}\left(\eta_{t+1}\right)} \\
& +U_{22} \tau_{t+1}^{2} w_{t+1}^{2}\left(1-\tilde{f}\left(\eta_{t+2}\right)\right)^{2} \\
& \left.\cdot\left[\alpha-(1-\alpha) \bar{n}_{t+1} \frac{f^{\prime}\left(n_{t+1}\right)}{1-\tilde{f}\left(\eta_{t+1}\right)}\right]^{2}+U_{33}\right] \\
& -\left[U_{11}\left(1-\tau_{t}\right) w_{t} f^{\prime}\left(n_{t+1}\right)\right. \\
& +U_{22} R_{t+1} \tau_{t+1} w_{t+1}\left(1-\tilde{f}\left(\eta_{t+2}\right)\right) \\
& \left.\cdot\left[\alpha-(1-\alpha) \bar{n}_{t+1} \frac{f^{\prime}\left(n_{t+1}\right)}{1-\tilde{f}\left(\eta_{t+1}\right)}\right]\right]^{2} \\
& =\left[U_{11}+R_{t+1}^{2} U_{22}\right]\left[-U_{1}\left(1-\tau_{t}\right) w_{t} f^{\prime \prime}\left(n_{t+1}\right)+U_{33}\right. \\
& \left.-U_{2} \tau_{t+1} w_{t+1}\left(1-\tilde{f}\left(\eta_{t+2}\right)\right)(1-\alpha) \bar{n}_{t+1} \frac{f^{\prime \prime}\left(n_{t+1}\right)}{1-\tilde{f}\left(\eta_{t+1}\right)}\right] \\
& +U_{11} U_{22}\left[\left(1-\tau_{t}\right) w_{t}\left[f^{\prime}\left(n_{t+1}\right)\right] R_{t+1}\right. \\
& -\tau_{t+1} w_{t+1}\left(1-\tilde{f}\left(\eta_{t+2}\right)\right) \\
& \left.\cdot\left[\alpha-(1-\alpha) \bar{n}_{t+1} \frac{f^{\prime}\left(n_{t+1}\right)}{1-\tilde{f}\left(\eta_{t+1}\right)}\right]\right]^{2} \\
& >0 \text {, }
\end{aligned}
$$

while the following conditions hold if a Beveridge scheme is in place:

$$
\begin{aligned}
U_{n n}= & -U_{1}\left(1-\tau_{t}\right) w_{t} f^{\prime \prime}\left(n_{t+1}\right)+U_{11}\left(1-\tau_{t}\right)^{2} w_{t}^{2}\left[f^{\prime}\left(n_{t+1}\right)\right]^{2} \\
& +U_{22} \tau_{t+1}^{2} w_{t+1}^{2}\left(1-\tilde{f}\left(\eta_{t+2}\right)\right)^{2} \alpha^{2}+U_{33} \\
< & 0
\end{aligned}
$$




$$
\begin{aligned}
U_{s s} U_{n n}-U_{n s} U_{s n}= & {\left[U_{11}+R_{t+1}^{2} U_{22}\right]\left[-U_{1}\left(1-\tau_{t}\right) w_{t} f^{\prime \prime}\left(n_{t+1}\right)\right.} \\
& +U_{11}\left(1-\tau_{t}\right)^{2} w_{t}^{2}\left[f^{\prime}\left(n_{t+1}\right)\right]^{2} \\
& \left.+U_{22} \tau_{t+1}^{2} w_{t+1}^{2}\left(1-\tilde{f}\left(\eta_{t+2}\right)\right)^{2} \alpha^{2}+U_{33}\right] \\
& -\left[U_{11}\left(1-\tau_{t}\right) w_{t} f^{\prime}\left(n_{t+1}\right)\right. \\
& \left.+U_{22} R_{t+1} \tau_{t+1} w_{t+1}\left(1-\tilde{f}\left(\eta_{t+2}\right)\right) \alpha\right]^{2} \\
= & {\left[U_{11}+R_{t+1}^{2} U_{22}\right]\left[-U_{1}\left(1-\tau_{t}\right) w_{t} f^{\prime \prime}\left(n_{t+1}\right)+U_{33}\right] } \\
& +U_{11} U_{22}\left[\left(1-\tau_{t}\right) w_{t}\left[f^{\prime}\left(n_{t+1}\right)\right] R_{t+1}\right. \\
& \left.-\tau_{t+1} w_{t+1}\left(1-\tilde{f}\left(\eta_{t+2}\right)\right) \alpha\right]^{2} \\
> & 0
\end{aligned}
$$

In each case, the objective function is strictly concave in the decision variables. 


\section{References}

Aaron, H., 1966. The social insurance paradox. Canadian Journal of Economics and Political Science 32, 371-374.

Abio, G., Mahieu, G., Patxot, C., 2002. On the optimality of PAYG pension systems in an endogenous fertility setting. IRES Discussing Paper No. 20026, Université catholique de Louvain.

Ahn, N., Mira, P., 2002. A note on the changing relationship between fertility and female employment rates in developed countries. Journal of Population Economics 15, 667-682.

Bental, B., 1989. The old age security hypothesis and optimal population growth. Journal of Population Economics 1, 285-301.

Cigno, A., 1993. Intergenerational transfers without altruism. Family, market and state. European Journal of Political Economy 9, 505-518.

Cigno, A., Rosati, F.C., 1996. Jointly determined saving and fertility behaviour: theory, and estimates for Germany, Italy, UK and USA. European Economic Review 40, 1561-1589.

Cigno, A., Casolare, L., Rosati, F.C., 2000. The role of social security in household decisions: VAR estimates of saving and fertility behavior in Germany. CESifo Working Paper No. 394, Munich.

Felderer, B., Ritzberger, K., 1995. Family allowances as welfare improvements. Journal of Economics 61, 11-33.

Gaggermeier, C., Lucke, B., 2002. Pension schemes and population growth. Working Paper, University of Hamburg.

Kögel, T., 2002. Did the association between fertility and female employment within OECD countries really change its sign? Working Paper, Max Planck Institute for Demographic Research, Rostock.

Kolmar, M., 1997. Intergenerational redistribution in a small open economy with endogenous fertility. Journal of Population Economics 10, 335-356.

Kolmar, M., 2001. Optimal intergenerational redistribution in a two-country model with endogenous fertility. Public Choice 106, 23-51.

Peters, W., 1995. Public pensions, family allowances and endogenous demographic change. Journal of Population Economics 8, 161-183.

Sinn, H.-W., 1998. The pay-as-you-go pension system as a fertility insurance and enforcement device. NBER Working Paper No. 6610, Cambridge.

Sinn, H.-W., 2001. The value of children and immigrants in a pay-as-you-go pension system: a proposal for a transition to a funded system. ifo Studien $47,77-94$. 
van Groezen, B., Leers, T., Meijdam, L., 2000. Family size, looming demographic changes and the efficiency of social security reform. CentER Working Paper No. 2000-27, Tilburg.

van Groezen, B., Leers, T., Meijdam, L., 2003. Social security and endogenous fertility: pensions and child allowances as Siamese twins. Journal of Public Economics 87, 233-251.

Wigger, B.U., 1999. Pay-as-you-go financed public pensions in a model of endogenous growth and fertility. Journal of Population Economics 12, 625640.

Zhang, Jie, 1995. Social security and endogenous growth. Journal of Public Economics 58, 185-213. 


\title{
CESifo Working Paper Series
}

\author{
(for full list see www.cesifo.de)
}

815 Rainer Niemann and Dirk Simons, Costs, Benefits, and Tax-induced Distortions of Stock Option Plans, December 2002

816 Jan-Egbert Sturm and Barry Williams, Deregulation, Entry of Foreign Banks and Bank Efficiency in Australia, December 2002

817 V. Anton Muscatelli, Patrizio Tirelli, and Carmine Trecroci, Monetary and Fiscal Policy Interactions over the Cycle: Some Empirical Evidence, December 2002

818 Claude Hillinger, A General Theory of Price and Quantity Aggregation and Welfare Measurement, December 2002

819 Erkki Koskela and Ronnie Schöb, Optimal Capital Taxation in Economies with Unionised and Competitive Labour Markets, December 2002

820 Sheilagh Ogilvie, Guilds, Efficiency, and Social Capital: Evidence from German ProtoIndustry, December 2002

821 Hans Gersbach and Verena Liessem, Financing Democracy, December 2002

822 Costas Hadjiyiannis, Panos Hatzipanayotou, and Michael S. Michael, Optimal Tax Policies with Private-Public Clean-Up, Cross-Border Pollution and Capital Mobility, December 2002

823 François Ortalo-Magné and Sven Rady, Homeownership: Low Household Mobility, Volatile Housing Prices, High Income Dispersion, December 2002

824 Syed M. Ahsan and Panagiotis Tsigaris, Measuring the Social Discount Rate under Uncertainty: A Methodology and Application, December 2002

825 Kai A. Konrad, Altruism and Envy in Contests: An Evolutionarily Stable Symbiosis, December 2002

826 Robert S. Chirinko and Huntley Schaller, A Revealed Preference Approach to Understanding Corporate Governance Problems: Evidence from Canada, December 2002

827 Geir B. Asheim, Green National Accounting for Welfare and Sustainability: A Taxonomy of Assumptions and Results, December 2002

828 Andrea Gebauer, Chang Woon Nam, and Rüdiger Parsche, Lessons of the 1999 Abolition of Intra-EU Duty Free Sales for Eastern European EU Candidates, December 2002 
829 Giacomo Corneo, Work and Television, December 2002

830 Vivek H. Dehejia and Yiagadeesen Samy, Trade and Labour Standards - Theory, New Empirical Evidence, and Policy Implications, December 2002

831 Geir B. Asheim and Wolfgang Buchholz, A General Approach to Welfare Measurement through National Income Accounting, December 2002

832 Aaron Tornell and Frank Westermann, The Credit Channel in Middle Income Countries, January 2003

833 Gebhard Flaig, Time Series Properties of the German Monthly Production Index, January 2003

834 Campbell Leith and Jim Malley, Estimated Open Economy New Keynesian Phillips Curves for the G7, January 2003

835 Burkhard Heer and Bernd Süssmuth, Inflation and Wealth Distribution, January 2003

836 Erkki Koskela and Leopold von Thadden, Optimal Factor Taxation under Wage Bargaining - A Dynamic Perspective, January 2003

837 Carola Grün and Stephan Klasen, Growth, Income Distribution, and Well-Being: Comparisons across Space and Time, January 2003

838 Robert S. Chirinko and Ulf von Kalckreuth, On the German Monetary Transmission Mechanism: Interest Rate and Credit Channels for Investment Spending, January 2003

839 Sascha O. Becker, Andrea Ichino, and Giovanni Peri, How Large is the "Brain Drain" from Italy?”, January 2003

840 Albert Berry and John Serieux, All About the Giants: Probing the Influences on Growth and Income Inequality at the End of the $20^{\text {th }}$ Century, January 2003

841 Robert Fenge and Martin Werding, Ageing and the Tax Implied in Public Pension Schemes: Simulations for Selected OECD Countries, January 2003

842 Robert Fenge and Martin Werding, Ageing and Fiscal Imbalances Across Generations: Concepts of Measurement, January 2003

843 Giovanni Andrea Cornia, The Impact of Liberalisation and Globalisation on Income Inequality in Developing and Transitional Economies, January 2003

844 Peter Fredriksson and Per Johansson, Program Evaluation and Random Program Starts, January 2003

845 Bernd Hayo and Matthias Wrede, Fiscal Equalisation: Principles and an Application to the European Union, January 2003

846 Syed M. Ahsan and Jaideep Oberoi, Inequality, Well-being and Institutions in Latin America and the Caribbean, January 2003 
847 Chang Woon Nam and Doina Maria Radulescu, The Role of Tax Depreciation for Investment Decisions: A Comparison of European Transition Countries, January 2003

848 V. Bhaskar and Steinar Holden, Wage Differentiation via Subsidised General Training, January 2003

849 Paloma Lopez-Garcia, Labour Market Performance and Start-up Costs: OECD Evidence, January 2003

850 Christian Keuschnigg and Soren Bo Nielsen, Public Policy for Start-up Entrepreneurship with Venture Capital and Bank Finance, January 2003

851 Yin-Wong Cheung, Menzie D. Chinn, and Eiji Fujii, China, Hong Kong, and Taiwan: A Quantitative Assessment of Real and Financial Integration, January 2003

852 Gregory D. Hess, The Economic Welfare Cost of Conflict: An Empirical Assessment, February 2003

853 Douglas J. Cumming and Jeffrey G. MacIntosh, Comparative Venture Capital Governance. Private versus Labour Sponsored Venture Capital Funds, February 2003

854 Eckhard Janeba and John Douglas Wilson, Decentralization and International Tax Competition, February 2003

855 Tapio Palokangas, Capital Accumulation and Employment Cycles in a Model of Creative Destruction, February 2003

856 Brendan Walsh, When Unemployment Disappears: Ireland in the 1990s, February 2003

857 Luis H. R. Alvarez and Erkki Koskela, A General Approach to the Stochastic Rotation Problem with Amenity Valuation, February 2003

858 Christian Schultz, Strategic Campaigns and Redistributive Politics, February 2003

859 Ernst Fehr and Joseph Henrich, Is Strong Reciprocity a Maladaptation? On the Evolutionary Foundations of Human Altruism, February 2003

860 Haizhou Huang, Dalia Marin, and Chenggang Xu, Financial Crisis, Economic Recovery and Banking Development in Former Soviet Union Economies, February 2003

861 Pedro Cardoso and Bernard M.S. van Praag, How Sustainable Are Old-age Pensions in a Shrinking Population with Endogenous Labour Supply?, February 2003

862 Volker Meier, Efficient Transfer of Aging Provisions in Private Health Insurance, February 2003

863 Edward Castronova, Theory of the Avatar, February 2003 
864 Robert S. Chirinko, Hans van Ees, Harry Garretsen, and Elmer Sterken, Investor Protections and Concentrated Ownership: Assessing Corporate Control Mechanisms in the Netherlands, February 2003

865 Bernard M.S. van Praag and Pedro Cardoso, The Mix Between Pay-as-you-go and Funded Pensions and what Demography has to do with it, February 2003

866 Ernst Fehr, Urs Fischbacher, Bernhard von Rosenbladt, Jürgen Schupp, and Gert G. Wagner, A Nation-Wide Laboratory. Examining Trust and Trustworthiness by Integrating Behavioral Experiments into Representative Survey, February 2003

867 Frank Heinemann, The Inflationary Impact of Wage Indexation, February 2003

868 Eytan Sheshinski, Bounded Rationality and Socially Optimal Limits on Choice in a Self-Selection Model, February 2003

869 M. Hashem Pesaran, Estimation and Inference in Large Heterogenous Panels with Cross Section Dependence, February 2003

870 Luis H. R. Alvarez and Erkki Koskela, On the Tree-Cutting Problem under Interest Rate and Forest Value Uncertainty, February 2003

871 Norbert Berthold and Rainer Fehn, Unemployment in Germany: Reasons and Remedies, February 2003

872 Clemens Fuest, Bernd Huber, and Philipp Tilleßen, Tax Policy and Entrepreneurship in the Presence of Asymmetric Information in Capital Markets, February 2003

873 Eytan Sheshinski, Optimum and Risk-Class Pricing of Annuities, February 2003

874 Willi Leibfritz, Paul O'Brien and Jean-Christophe Dumont, Effects of Immigration on Labour Markets and Government Budgets - An Overview, February 2003

875 M. Hashem Pesaran and Allan Timmermann, How Costly is it to Ignore Breaks when Forecasting the Direction of a Time Series?, February 2003

876 Thorvaldur Gylfason and Gylfi Zoega, Education, Social Equality and Economic Growth: A View of the Landscape, February 2003

877 Robin Boadway and Jean-François Tremblay, Public Economics and Startup Entrepreneurs, February 2003

878 Erkki Koskela and Roope Uusitalo, The Un-Intended Convergence: How the Finnish Unemployment Reached the European Level, February 2003

879 Robert Fenge and Volker Meier, Pensions and Fertility Incentives, February 2003 